Original Research Article

\title{
Comparative efficacy of melatonin in attenuation of endotoxin/LPS induced hepatotoxicity in BALB/c mice
}

\author{
Ammara Khan $^{1 *}$, Ayesha Afzal' ${ }^{2}$, Abdul Rauf $^{3}$, Akbar Waheed $^{4}$
}

${ }^{1}$ Department of Pharmacology and Therapeutics, Nawaz Sharif Medical College, University of Gujrat, Gujrat, Punajb, Pakistan ${ }^{2}$ Department of Pharmacology and Therapeutics, Wah Medical College, Wah Cantt, Wah, Pakistan

${ }^{3}$ Department of Pathology, Nawaz Sharif Medical College, University of Gujrat, Gujrat Punajb, Pakistan ${ }^{4}$ Department of Pharmacology and Therapeutics, Islamic International Medical College, Riphah International University, Islamabad, Pakistan

Received: 08 April 2018 Accepted: 01 May 2018

*Correspondence to:

Dr. Ammara Khan,

Email: Drammara19@ gmail.com

Copyright: (C) the author(s), publisher and licensee Medip Academy. This is an openaccess article distributed under the terms of the Creative Commons Attribution NonCommercial License, which permits unrestricted noncommercial use, distribution, and reproduction in any medium, provided the original work is properly cited.

\begin{abstract}
Background: Sepsis is characterized by overwhelming surge of cytokines and oxidative stress to one of many factors, gram negative bacteria commonly implicated. Despite major expansion and elaboration of sepsis pathophysiology and therapeutic approach; death rate remains very high in septic patients due to multiple organ damage including hepatotoxicity. The present study was aimed to ascertain the adequacy of melatonin $(10 \mathrm{mg} / \mathrm{kg}$ i.p), and its comparability with dexamethasone (3mg/kg i.p), delivered separately and collectively in endotoxin induced hepatotoxicity.

Methods: The number of animals in each group was six. Endotoxin/LPS induced hepatotoxicity was reproduced in mice by giving LPS of serotype $E$. coli intraperitoneally. Preventive role was questioned by giving the experimental agent half an hour prior to LPS injection whereas therapeutic potential of the experimental agent was searched out via post LPS delivering. The extent of liver damage was adjudged via serum alanine aminotransferases (ALT) and aspartate aminotransferase (AST) estimation along with histopathological examination of liver tissue.
\end{abstract}

Results: Melatonin was prosperous in aversion (Group 3) and curation (Group 4) of LPS invoked hepatotoxicity as evident by lessening of augmented ALT $(\leq 0.01)$ and AST $(\leq 0.01)$ along with restoration of pathological changes on liver sections $(\mathrm{p} \leq 0.05)$. Dexamethasone given before (Group5) and after LPS (Group 6) significantly $(p \leq 0.05)$ attenuated LPS generated liver injury. Combination therapy with dexamethasone in conjunction with melatonin (Group 7) after LPS administration tapered LPS evoked hepatic dysfunction statistically considerably, however the result was comparable to single agent therapy.

Conclusions: Melatonin set up promising results in endotoxin induced hepatotoxicity and can be used therapeutic adjuncts to conventional treatment strategies in sepsis induced liver failure. Combination therapies however generated no synergistic results.

Keywords: Dexamethasone, Endotoxin, Hepatotoxicity, LPS, Melatonin

\section{INTRODUCTION}

Human immune response is a mixed blessing; besides protecting human body from deadly infections by pathogens, a hyper immune response to multiple factors producing a great deal of inflammatory mediators results in systemic inflammation, intravascular coagulation, tissue injury and sepsis. Sepsis presents a major health burden globally with $10^{\text {th }}$ leading cause of death in USA and Asian aged 65-85 years and $5^{\text {th }}$ leading cause of death in Asian 
children of age 5-10 years. Sepsis contributes to $6 \%$ of all deaths in USA, costing them about 16.7 billion dollars annually. ${ }^{1}$ The rate of sepsis associated organ failure has also convincingly escalated from 1.62 in 2000 to 1.90 in 2007 in USA with respiratory and renal organ mostly involved followed by liver. ${ }^{2}$ The exact incidence of liver dysfunction in sepsis is not reported due to deficiency of exact definitions, laboratory cut off values and observation times. However, given the indispensable role of liver in almost all metabolic processes, immune response and bacterial and endotoxin scavenging and detoxification, its integrity is necessary for human survival. As documented by worldwide non-interventional PROGRESS study in 2009, gram-negative bacteria were main offender in $57.3 \%$ of septic patients, triggering sequel of systemic inflammation and multiple organ failure through Bacterial Lipopolysaccharide (LPS), a glycolipid component of its cell wall. ${ }^{3}$ Activation of TLR4 receptors on Kupffer cells by LPS elicits production of inflammatory cytokines including TNF-alpha, various interleukins (ILs), reactive oxygen-nitrogen species, lipid mediators like thromboxane $\mathrm{A} 2$, and proteases ; all producing hepatocytes dysfunction in counteraction to LPS. ${ }^{4}$

Coexisting distorted hypothalamic pituitary adrenal axis and transient adrenal failure occurring in almost $50 \%$ of patients proves devastating as hemodynamic inconstancy and accentuation of inflammation in sepsis. ${ }^{5}$ Studies document that low dose steroid therapy $(300 \mathrm{mg} /$ day hydrocortisone or equivalent) expedite shock reversal, amends hemodynamic instability through up regulation of catecholamine receptors which were desensitized by high cortisol levels and decline production of NO markedly decreases inflammatory mediators TNF-alpha, IL-10, IL6 , IL-8, C-reactive proteins, and reduces the severity of organ failure including hepatotoxicity. ${ }^{6-10}$ However corticosteroid use in septic patients is lumped together with more adverse effects like higher stakes of super infection including new episodes of sepsis. Further not known are the most favorable dosage schedule and which septic population to be treated. Data regarding criteria to adjudge adrenal failure in severe septic patient and method of tapering is also not compete. ${ }^{11-13}$ As a result of this debate on steroid use in sepsis, researchers drive to find new treatment modalities.

Derived from amino acid tryptophan, melatonin in an indole hormone of pineal gland and select extra pineal organs having plentitude physiological and pharmacological actions. Melatonin by dint of wellillustrated trans-membrane receptors MT1 and MT2 carry out multiple physiological functions in human body like inhibition of suprachiasmatic nucleus neuronal firing, inhibits prolactin and cortisol secretion from anterior pituitary, inhibits leydig cells testosterone secretion, regulates uterine contraction and oxytocin receptor expression, modulates immune function and insulin secretion and has sedative, analgesic and anxiolytic actions. Direct radical scavenging capacity, up-regulation of activity and synthesis of important antioxidant enzymes like Glutathione peroxidase and glutathione reductase and prevention of mitochondrial transition pore opening and following apoptosis via accentuating activity of complex I and complex IV of electron transport chain, all contribute to melatonin efficacy in reducing oxidative stress. ${ }^{14}$ Sewerynek and coworkers in 1995 firstly demonstrated reversal of LPS mediated increase in lipid peroxidation, decline in antioxidant Glutathione and hepatocytes degeneration by melatonin. ${ }^{15}$ Studies has documented beneficial role of melatonin in sepsis induced hepatotoxicity via reduction of inflammatory mediators TNF- $\alpha$, IL-12, IL-6, IL-8, anti-apoptotic activity via escalation of IL-10, contracted nuclear factor $\kappa \mathrm{B}(\mathrm{NF}-\kappa \mathrm{B})$ activation, inducible nitric oxide synthase (iNOS) appearance and transcription with resultant diminished nitrite production and improvement of electron transport chain , mitochondrial respiration and ATP synthesis. ${ }^{16-18}$

Immense work done in laboratory and clinical trials contributed to improved and extensive understanding of pathophysiology of sepsis induced organ failure and affected population. But dishearteningly the treatment of sepsis has not thus far expanded remoter than use of fluid, sampling, prompt administration of antibiotics, rigid glycemic control, source drainage and vasopressors use. ${ }^{19,20}$ Newer diagnostic and treatment modalities can benefit in reducing anguish and lethality related to sepsis.

This study was drafted to appraise and compare the effectiveness of dexamethasone and melatonin in prevention and treatment of lipopolysaccharides induced hepatotoxicity in mice.

Following are the objectives of our study:

- To study the extent of hepatotoxicity induced by gram negative bacterial (E. coli) lipopolysaccharides.

- To determine the prophylactic and therapeutic role of dexamethasone and melatonin lipopolysaccharidesinduced hepatotoxicity.

- To compare the individual and combined role of above mentioned drugs in LPS induced liver damage.

\section{METHODS}

\section{Study design}

A Randomized Controlled Laboratory Trial was carried out in accordance to study protocols endorsed by The Ethical committee of "Centre of Research in Experimental and applied Medicine (CREAM)" Army Medical College, NUST. White albino mice of both gender, weight 40-50 grams, age 8-12 weeks and without any previous treatment taken were selected and randomly divided into 10 groups with at least 8 animals per group. All animals were housed under standard conditions in traditional wire topped cages with temperature ranging from $20-22^{\circ} \mathrm{C}$ and humidity maintained at $40-70 \%$. Nutritionally proficient rodent pellet diet and contamination free fresh water were provided ad lithium. 


\section{Experimental agents}

Lipopolysaccharides (LPS) From Escherichia Coli O111:B4, purchased from Sigma Aldrich, was dissolved in phosphate buffered saline in a sterilized falcon tube and shaken to mix thoroughly. Dose selected was $10 \mathrm{mg} / \mathrm{kg}$ intraperitoneally. ${ }^{21}$ Dexamethasone, purchased from Amros Pharmaceuticals, Pakistan with $3 \mathrm{mg} / \mathrm{kg}$ intraperitoneally as applicable dose. ${ }^{21,22}$ Melatonin was purchased from Sigma Aldrich Chemical, USA as granular powder in amber coloured glass bottle and stored at $-20^{\circ} \mathrm{C}$. $10 \mathrm{mg} / \mathrm{kg}$ intraperitoneally was selected dose. ${ }^{23}$

\section{Experimental approach}

\section{Generation of LPS Induced Hepatotoxic Model}

A pilot project was conducted to estimate the hepatotoxic dose of LPS in this white albino mice. Initially the dose and time interval before dissection was selected on the basis of researches already undertaken, $10 \mathrm{mg} / \mathrm{kg}$ of body weight and time interval of 8 hours. Nevertheless, this strategy proved ineffectual and failed to produced marked hepatotoxicity. A satisfactory hepatotoxic model was devised several weeks later. To evaluate the role of experimental agents, dexamethasone and melatonin, in aversion of endotoxin induced hepatic dysfunction; agents were administered 30 minutes before intraperitoneal administration of LPS.

This time is selected on the basis of drugs kinetics and previous studies. The remedial or therapeutic role of same agents in endotoxin induced hepatotoxicity was determined by giving drugs 2 hour after intraperitoneal administration of LPS.

The 2 hour time interval between LPS and drug administration was chosen on basis of previous studies which indicate that inflammatory cytokine levels peak after 1 hour of LPS administration. ${ }^{24}$ Dexamethasone was administered once whereas melatonin was given twice due to rapid elimination kinetics.

\section{Blood and sample and tissue collection}

\section{Blood collection}

Primary blood sampling in all animals was done from lateral tail vein of mouse according to protocols approved by Institutional Animal Care and Use Committee (IACUC). Blood was collected in microcapillary inserted into pipette bulb followed by sample dispensing into Eppendorf tube. Hemostasis was ensured. All initial blood samples were stored at $4^{\circ} \mathrm{C}$.

Terminal anesthesia was given by ether using drop jar method. Closed Ventral approach was adopted for terminal sampling by cardiac puncture with mouse was positioned in dorsal recumbancy.

\section{Tissue collection and processing}

After midline laparotomy by sharp scissors, liver was identified in the right upper quadrant of abdominal cavity. Liver was then pushed out of the abdominal cavity, washed off excess blood and immediately fixed in $10 \%$ neutral buffered formalin in plastic container labeled with group name and treatment received. Tissue blocks placed in labelled tissue cassettes were processed in LEICA TP 1020 AUTOMATIC TISUUE Processor and latter stained with hematoxylin and eosin for light microscopy.

Table 1: Grouping outline.

\begin{tabular}{|c|c|c|}
\hline $\begin{array}{l}\text { Group } \\
\text { name }\end{array}$ & $\begin{array}{l}\text { Treatment } \\
\text { received }\end{array}$ & Dose of drug \\
\hline $\begin{array}{l}\text { Group } 1 \\
\text { (control) }\end{array}$ & i.p normal saline & $0.5 \mathrm{ml}$ \\
\hline $\begin{array}{l}\text { Group } 2 \\
\text { (LPS) }\end{array}$ & i.p LPS & $\begin{array}{l}10 \mathrm{mg} / \mathrm{kg} \text { of } \\
\text { body weight }\end{array}$ \\
\hline $\begin{array}{l}\text { Group } 3 \\
\text { (mela pre) }\end{array}$ & $\begin{array}{l}\text { i.p melatonin } \\
\text { followed 30minutes } \\
\text { after by i.p LPS }\end{array}$ & $\begin{array}{l}\text { Melatonin } \\
10 \mathrm{mg} / \mathrm{kg} \text { of } \\
\text { body weight }\end{array}$ \\
\hline $\begin{array}{l}\text { Group } 4 \\
\text { (mela post) }\end{array}$ & $\begin{array}{l}\text { i.p LPS followed } 2 \\
\text { hour after by } 1^{\text {st }} \\
\text { dose i.p melatonin } \\
\text { and } 2^{\text {nd }} \text { dose after } \\
\text { an additional one } \\
\text { hour. }\end{array}$ & $\begin{array}{l}\text { Melatonin } \\
10 \mathrm{mg} / \mathrm{kg} \text { of } \\
\text { body weight }\end{array}$ \\
\hline $\begin{array}{l}\text { Group } 5 \\
\text { (dexa pre) }\end{array}$ & $\begin{array}{l}\text { i.p dexamethasone } \\
\text { followed } 30 \\
\text { minutes after by } \\
\text { LPS }\end{array}$ & $\begin{array}{l}\text { Dexamethasone } \\
3 \mathrm{mg} / \mathrm{kg} \text { of body } \\
\text { weight }\end{array}$ \\
\hline $\begin{array}{l}\text { Group } 6 \\
\text { (dexa post) }\end{array}$ & $\begin{array}{l}\text { i.p LPS followed } 2 \\
\text { hour after by i.p } \\
\text { dexamethasone }\end{array}$ & $\begin{array}{l}\text { Dexamethasone } \\
3 \mathrm{mg} / \mathrm{kg} \text { of body } \\
\text { weight }\end{array}$ \\
\hline $\begin{array}{l}\text { Group } 7 \\
(\text { dexa+mela) }\end{array}$ & $\begin{array}{l}\text { Simultaneously } \\
\text { with } \\
\text { IPdexamethasone } \\
\text { and melatonin, } 2 \\
\text { hours after } \\
\text { administration of } \\
\text { LPS. One more } \\
\text { melatonin dose was } \\
\text { injected } 60 \text { minutes } \\
\text { later. }\end{array}$ & $\begin{array}{l}\text { Dexamethasone } \\
\text { ( } 3 \mathrm{mg} / \mathrm{kg} \text { of body } \\
\text { weight) and } \\
\text { melatonin } \\
\text { (10mg/kg of } \\
\text { body weight) }\end{array}$ \\
\hline
\end{tabular}

\section{Hepatic dysfunction assessment}

Hepatic failure was determined through analysis of serum ALT and serum AST and histopathological examination of liver sections. Non-specific varied histopathological changes in liver ranging from bland cytoplasm, vesicular and enlarged nuclei, cell swelling, sinusoidal inflammation, portal inflammation, centrilobular and lobular necrosis to cholangitis were looked for and graded using Ishak Modified Histological Activity Index (Brunt, 2000) to grade histopathological changes in liver. ${ }^{25,26}$ As 
duration of this study was short, fibrosis was not looked for. ${ }^{27}$

\section{Statistical analysis}

Data was entered in statistical package for social sciences (SPSS) version 20. The results of the serum analysis were expressed as Means + Standard Error of Means. The statistical significance of differences between means were analyzed with one way analysis of variance (ANOVA) followed by Post-hoc tukey test. Statistical difference between serum marker at initial and final hours were found using Paired T-test. Independent / unpaired T-test was utilized to access difference of serum markers at 17 hours on LPS group with another. The result of histopathology was analyzed using the "Chi-square test". All values were considered statistically significant if " $p$ value" was equal or less than 0 .

\section{RESULTS}

\section{Chemical parameters analysis}

Mean serum ALT and AST levels of all animals of Group 1 (control group) were not significantly risen at 17 hours yielding a inconsequential $\mathrm{p}$ value through paired student T-test (Table 2). Endotoxin receiving mice of Group 2 (LPS group) appeared worn-down, immobile and took less feed and water as compared to mice of Group 1(control group) during 17 hours of the experimental period. Serum ALT level significantly ( $\mathrm{p} \leq 0.05$ ) mounted to 345.17 $\mathrm{IU} / \mathrm{L} \pm 76.51$ at 17 hours from $106.00 \mathrm{IU} / \mathrm{L} \pm 2.81$ at 0 hours. Serum AST levels also showed similar patterns with values considerably accelerating, yeilding a statistically significant difference ( $\mathrm{p} \leq 0.001)$ (Table 2). When melatonin was given intraperitoneally to mice of Group 3(Melatonin pre-treatment group) before LPS administration, results indicate a statistically negligible change in serum ALT and AST levels. Prior to any treatment at 0 hour, the ALT was $108.83 \mathrm{IU} / \mathrm{L} \pm 1.17$ and after drug intervention was $113.71 \mathrm{IU} / \mathrm{L} \pm 5.71$. $\mathrm{P}$ value was 0.120 . Correspondingly serum AST revised to 118.83 IU/L \pm 14.44 at 17 hours from $96.17 \mathrm{IU} / \mathrm{L} \pm 1.62$ at 0 hour (p value 0.172 ). Similarly a statistically irrelevant change was observed in mice of Group 4(Melatonin post treatment group) when given melatonin after LPS administration. Results set forth that when dexamethasone was administered before intraperitoneal injection of LPS in mice of Group 5(dexamethasone pretreatment group), serum markers were not significantly different at 0 and 17 hours. Group 6 (dexamethasone post treatment) animals showed results analogous to Group 5. Serum AST and ALT did not profoundly ascended at 17 hours, generating a statistically insignificant $\mathrm{p}$ value. Results of this study brings forward that when dexamethasone and melatonin were co-administrated to mice of Group 7, serum ALT and AST at 17 hours reformed to the levels comparable to other groups. The serum markers (ALT and AST) levels at 17hours were statistically significant when Group 2 (LPS group) was compared with group 3,4,5 and 6, (Figure 1 and Figure 2), indication protective effect of melatoin and dexamethasone.

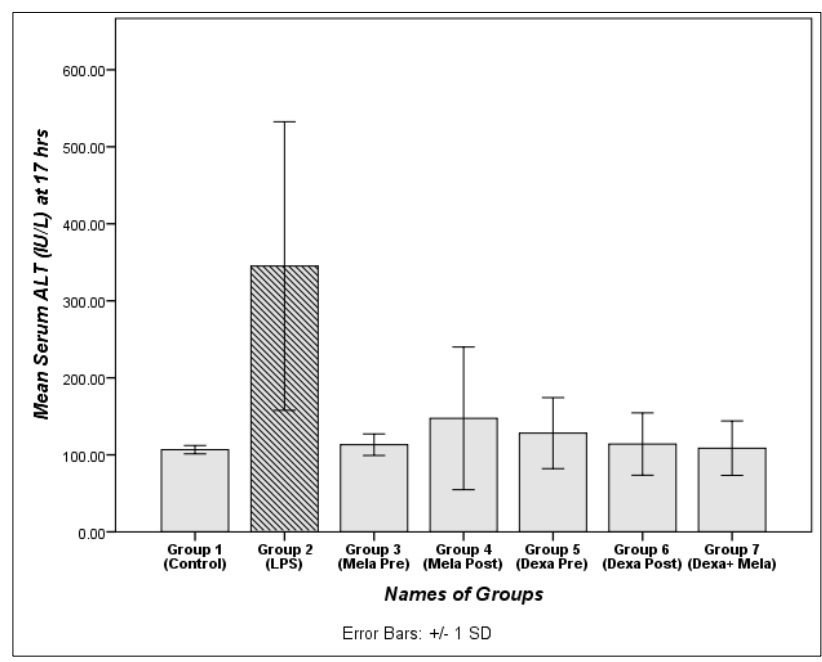

${ }^{*} \mathrm{p}<0.05$ vs group 1 (control), \#p $<0.05$ vs LPS; $\times \mathrm{p} 0>.05$ vs Group 3 (mela pre) $+\mathrm{p}>0.05$ vs group 4 (mela post) $; \sum \mathrm{p}>0.05$ vs group $3,4,5,6$

Figure 1: Mean serum ALT levels in treated mice at 17 hours.

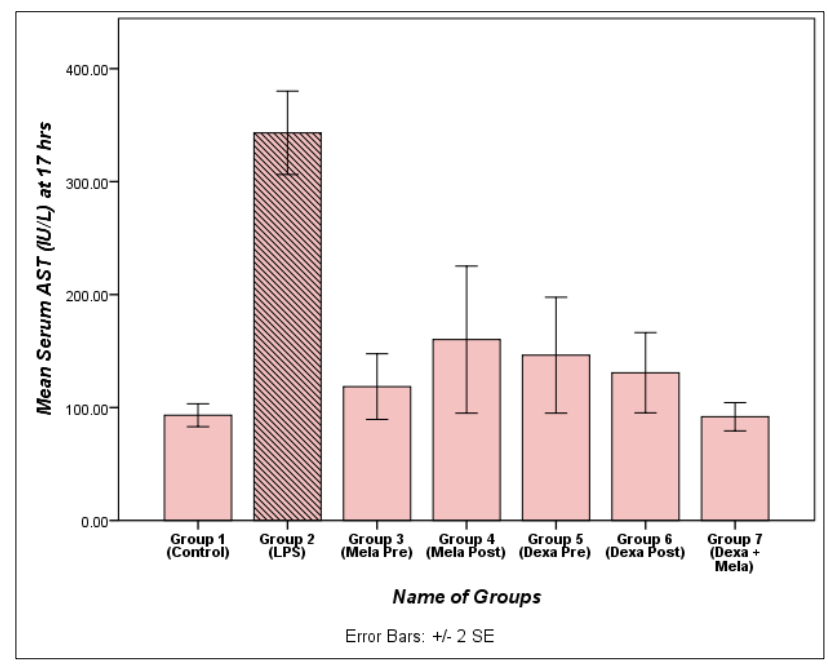

${ }^{*} \mathrm{p}<0.05$ vs group 1 (control), \#p<0.05 vs LPS; $\times \mathrm{p} 0>.05$ vs Group 3 (mela pre) $+\mathrm{p}>0.05$ vs group 4 (mela post) $\sum \sum \mathrm{p}>0.05$ vs group $3,4,5,6$.

\section{Figure 2: Mean serum AST (IU/L) levels in treated mice at 17 hours.}

\section{Histopathological analysis}

Histopathological analysis of sections of liver of six animals of Group 1 showed the normal lobular organization of mouse liver. Hepatic triad consisting of portal vein, a branch of hepatic artery along with bile duct was seen. Also hepatocytes cord, separated by sinusoids, are seen radiating from central venule (Figure 3). All six slides were graded as normal according to Ishak's criteria. Moderate inflammatory cells in filtrates around almost all portal areas, apoptotic changes in cells, and mild periportal 
inflammation in few portal areas were predominant inflammatory changes seen during the light microscopy of hepatic cross sections of animals of Group 2 that received
LPS/Endotoxin (Figure 4) so accordingly $70 \%$ of animals were categorized to have moderate to marked inflammation.

Table 2: Mean serum and \pm SEM ALT(IU/L) level and AST (IU/L) levels of all groups at 0hr and 17 hours.

\begin{tabular}{|lllllll|} 
& \multicolumn{2}{l}{ Mean serum and \pm SEM ALT levels } & \multicolumn{3}{l|}{ Mean serum and \pm SEM AST levels } \\
& At 0 hour & At 17 hour & P Value & At 0 hour & At 17 hour & P Value \\
\hline Group 1 (Control) & $109.5 \pm 3.09$ & $106.67 \pm 2.23$ & 0.276 & $90.50 \pm 4.82$ & $93.33 \pm 5.39$ & 0.137 \\
\hline Group 2 (LPS Group) & $106.00 \pm 2.81$ & $345.17 \pm 76.51$ & 0.024 & $90.50 \pm 4.82$ & $343.17 \pm 18.49$ & $\leq 0.001$ \\
\hline Group 3 (mela pre) & $100.83 \pm 1.17$ & $113.17 \pm 5.71$ & 0.120 & $96.17 \pm 1.62$ & $118.83 \pm 14.44$ & 0.172 \\
\hline Group 4 (mela post) & $101.33 \pm 3.02$ & $147.33 \pm 37.81$ & 0.262 & $97.83 \pm 3.57$ & $160.17 \pm 32.55$ & 0.117 \\
\hline Group 5 (dexa pre) & $103.00 \pm 3.98$ & $128.17 \pm 18.85$ & 0.181 & 96.33 & 146.33 & 0.115 \\
\hline Group 6 (dexa post) & $104.50 \pm 2.51$ & $114.00 \pm 16.55$ & 0.554 & $98.33 \pm 1.93$ & $130.83 \pm 17.77$ & 0.118 \\
\hline Group 7 (dexa+mela) & $100.17 \pm 4.14$ & $108.67 \pm 14.46$ & 0.459 & $92.00 \pm 2.83$ & $91.83 \pm 6.24$ & 0.975 \\
\hline
\end{tabular}

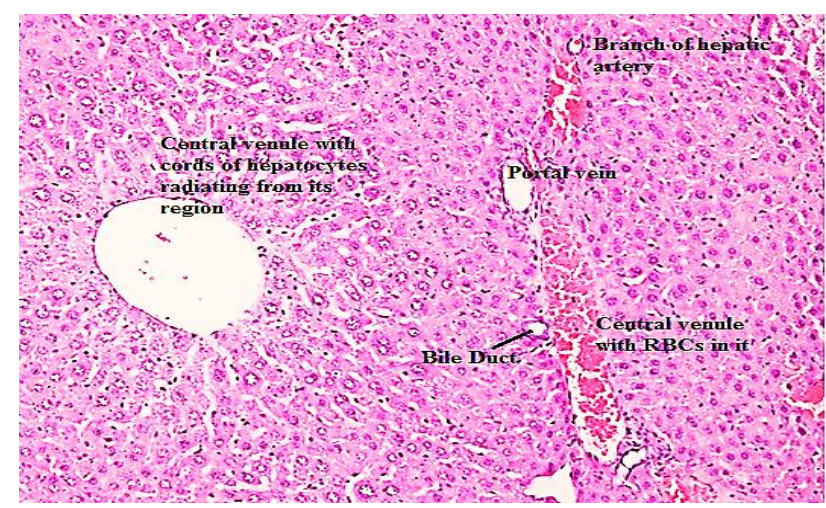

Figure 3: Group 1- Normal histology of Mouse Liver at $20 \mathrm{X}$ magnification.

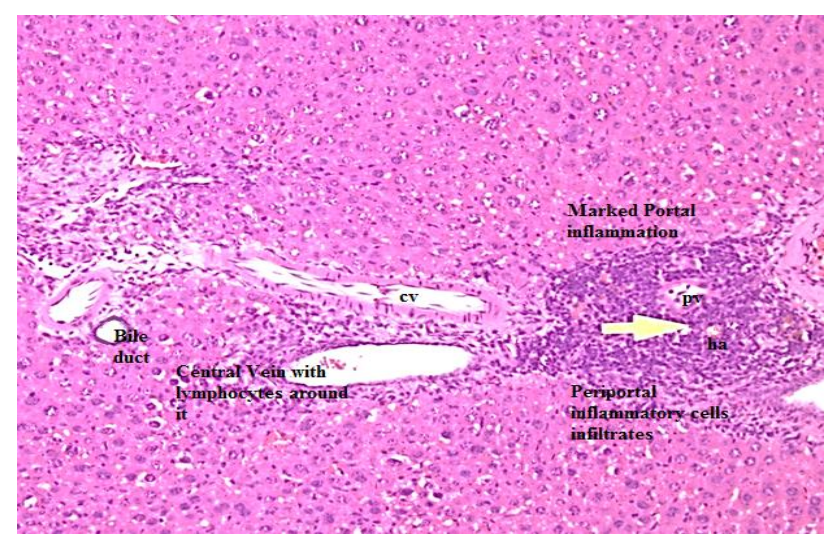

Figure 4: Group 2-LPS treated mouse liver histology at 20X). Cv-central vein, Pv-portal vein and Hahepatic artery.

Whereas melatonin pretreatment (Figure 5) in group 3, melatonin post treatment (Figure 6) in group 4 dexamethasone pretreatment (Figure 7) in group 5, dexamethasone post treatment (Figure 8) in group 6, and combined dexamethasone and melatonin treatment (Figure
9) in group 7 abolished LPS induced liver dystrophy and all $\mathrm{H}$ and $\mathrm{E}$ stained slides had minimal inflammation as observed under light microscopy. All these group yielded a statistically significant difference when compared to group 2 (LPS group) with $\mathrm{p} \leq 0.05$.

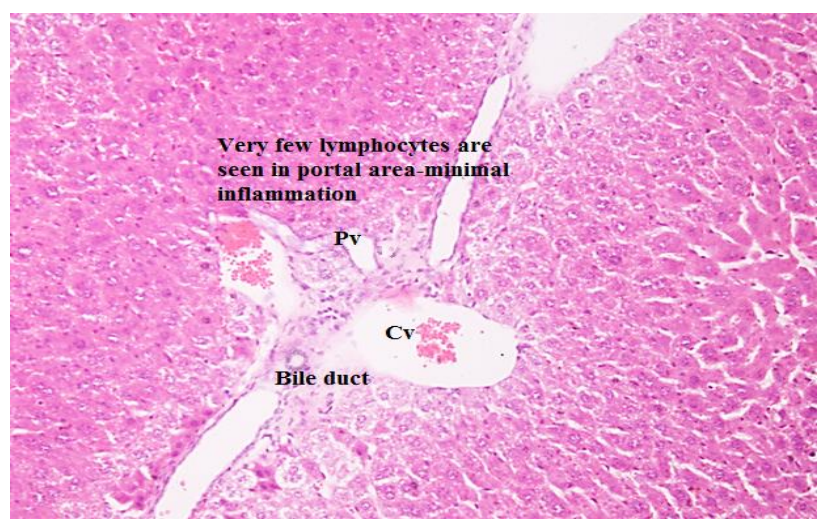

Figure 5: Group 3 (Melatonin pretreatment) mouse liver histology at 20X and 40X. Pv-portal vein, $\mathrm{Cv}$ centarl vein and Ha-hepatic arteriole.

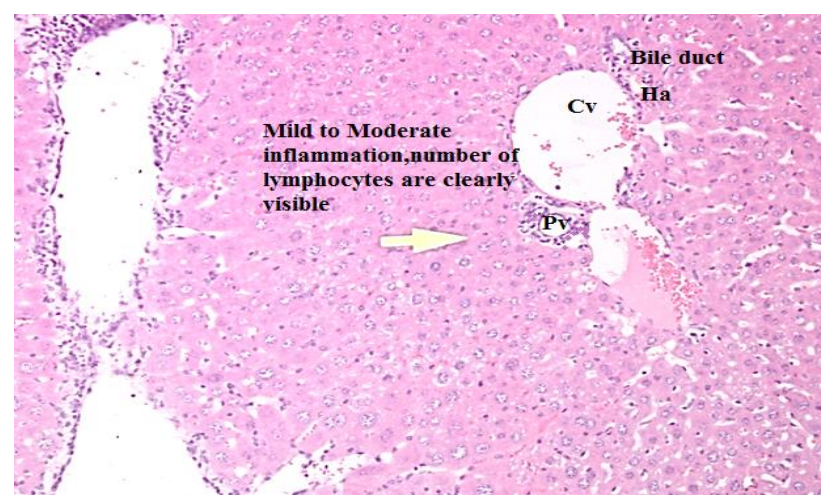

Figure 6: Group 4 (Melatonin post-treatment) mouse liver histology at 20X (Pv-portal vein, $\mathrm{Cv}$ centarl vein and Ha-hepatic arteriole. 


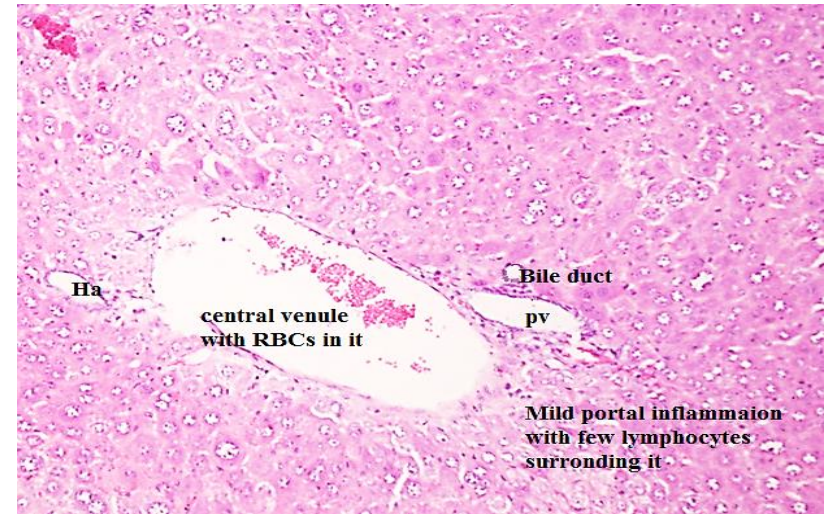

Figure 7: Group 5 (Dexamethasone pretreatment) mouse liver histology at 20X (Pv-portal vein, Hahepatic artery, $\mathrm{Cv}$-central vein.

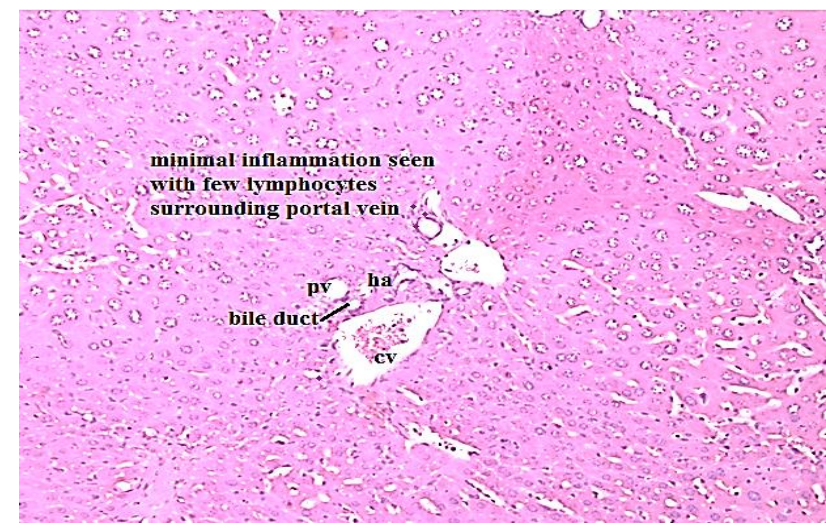

Figure 8: Group 6 (Dexamthasone post treatment) mouse liver histology at 20X (Pv-portal vein, $\mathrm{Cv}$ centarl vein and Ha-hepatic arteriole.

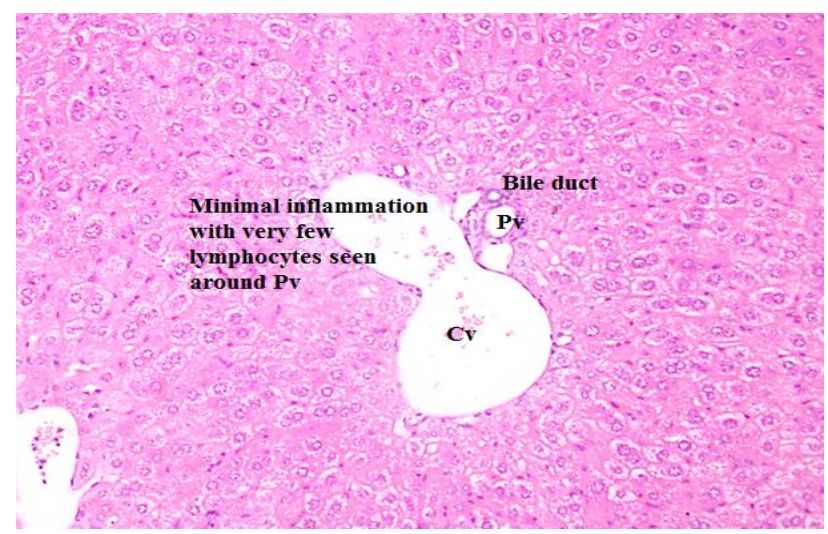

Figure 9: Group 7 (dexamethasone + melatonin combined $\mathbf{t} / \mathbf{m}$ ) mouse liver histology at $20 \mathrm{X}$.

\section{DISCUSSION}

Sepsis with symptoms of organ dysfunction as hepatotoxicity is one of the major killers especially in elderly population with Gram negative bacteria liable for $30-50 \%$ of cases due to high predominance of genitourinary infection in this area. ${ }^{28}$ Also livers promising involvement is nearly all biological functions, its malfunctioning in sepsis is thought to commence and aggravate other organ failure. ${ }^{4}$ The management plan of septic patient include infection source curbing, antiinfective agents administration and ensuring hemodynamic support. Regardless, $25-30 \%$ of septic patients die in hospital. Reassessment of current therapy along with evolution of new therapeutic adjuncts is the need of time to lessen associated escalating mortality and morbidity.

White albino mice were taken as this study tool as they have manageable housing and maneuvering, innate resistance to endotoxin, and holding a non-companion entity makes their use in survival studies more acceptable and ethical as opposed to larger animals like sheep, horses etc utilization. ${ }^{29}$ Serum ALT ans AST estimation are still acclaimed standast for liver assessment along with histopathological analysis of liver section for determination liver dysfunction. ${ }^{30}$ Several studies shared ISHAK /KNODELLS to be best hepatic histomorphological changes scoring system, not only in man but also in mouse and this led us to use this criteria to score liver degradation produced by endotoxin. ${ }^{31}$

Toxemia model was reproduced as this resulted in similar pathophysiological alterations are seen as in septic patients. ${ }^{32}$ Backed up by many studies, our mice became sluggish, innert and prostated after intraperitoneal injection of LPS/Endotoxin with highly deranged ALT and AST values and marked inflammation on liver cross sections. ${ }^{21,23,33,34}$

An ideal antioxidant should be versatile and comprehensive with throughout body distribution. It should also readily cross biological barrier and available in adequate concentration when required. Active metabolites possession and regeneration after radical scavenging activity with little toxicity to humans also make an antioxidant perfect. On this regard melatonin's antioxidant capability was explored in Group 3 and Group 4 and the data ensured us melatonin's ability to prevent the development of hepatotoxicity in response to LPS. Therapeutic efficacy was affirmed in group 4 where melatonin post treatment successfully restored ALT and AST concentrations and ameliorated inflammatory changes on liver section slides. Our findings were supported by Rishi and colleagues established that melatonin administration 30 minutes prior to LPS declined serum ALT, AST and alkaline phosphatase levels, upregulated liver glutathione and superoxide dismutase activity and amended LPS induced liver's histopathological irregularities. ${ }^{23}$ Crespo with his friends exhibited melatonin protective role in LPS induced liver damage as their results clearly displayed that melatonin given 30 minutes before LPS significantly decreased serum ALT, AST, alkaline phosphatase levels with reduced liver expression of iNOS expression. ${ }^{35}$ Further verifying melatonin's antioxidant, anti-apoptotic and antiinflammatory role in LPS induced liver damage are the 
results of Wang and associates. Melatonin successfully restored LPS evoked alterations in serum ALT levels and hepatic morphology, de-escalated LPS induced hepatic caspase- 3 and TNF- $\alpha$ activity along with intensifying hepatic anti-oxidants concentration. ${ }^{34}$ Melatonin pretreatment is also stated to preserve hepatic function, microcirculation and redox state in animal model of hemorrhagic shock. ${ }^{36} 10 \mathrm{mg} / \mathrm{kg}$ of melatonin before and after LPS has been shown to protect from LPS induced organ dysfunction through immunomodulation (reduced TNF- $\alpha$, IL-12 and increased IL-10 levels), radical scavenging action (diminished lipid peroxidation) and anti-apoptotic effect.

Study results resembles study outcome of Lowes and fellows in 2013. They authenticated that melatonin infusion after sepsis induction, lessened degree of liver inflammation and malfunction in animal model of sepsis as it reduced serum ALT, AST levels, declined oxidative damage and mitochondrial dysfunction. ${ }^{33}$ Rishi et al, and Crespo et al, also substantiate this study claim. Both the researchers along with their associates testified that melatonin intraperitoneal administration after LPS injection protects liver from endotoxin induced enzymatic distortions, oxidative stress and morphological alterations. $^{23,35}$ Melatonin has been shown to reduced mortality, abate sepsis induced oxidative damage and improve white blood cell and neutrophil count in septic newborns dosed twice with melatonin 12 hours after sepsis diagnosis. ${ }^{17} \mathrm{Wu}$ and friends in 2008 drew similar conclusion conformable to our data. Melatonin application 3 to 6 hours after sepsis induction curtailed markers of hepatic and renal injury, abridged liver tissue neutrophilic infiltration, and compressed plasma NO and IL-1 $\beta$ levels. ${ }^{37}$

Still having a questionable and dubious role, corticosteroids have proven beneficial in sepsis induced hepatic dysfunction and majority of septic patients with multiple organ failure arriving at hospital receive a steroid dose. Its potent anti-inflammatory role in sepsis induced hepatoxocity are associated to trans repression of NF- $\kappa \mathrm{B}$ and activated protein-1, induction of anti-inflammatory protein MAPK and annexin-1 and second messenger, phosphoinoitol-3-kinase(pi3K) regulation. In 2008, Wang and his colleagues demonstrated that $3 \mathrm{mg} / \mathrm{kg}$ of bodyweight of dexamethasone administration prior to high dose LPS administration reduced mortality rate by $100 \% .^{22}$

Also this dose is physiological and clinically relevant, hence selected as our test dose. Serum marker analysis in group 5 (dexamethasone pretreatment group) and group 6 (dexamethasone post treatment group) clearly demonstrated that dexamethasone holds the ability to curtail the LPS induced serum ALT and AST augmentation. Dexamethasone pretreatment in group 5 caused almost 63 percent decrease in serum ALT levels. Similar trend was observed in serum AST levels where dexamethasone cause 57 percent decline in group 4.
Also the architectural distortion produced by LPS in Group 2 was abated significantly $(\mathrm{p} \leq 0.01)$ by dexamethasone in Group 5. The results of group 6 (dexamethasone post treatment group) were not much different from those of group 5, that led us to infer that dexamethasone also hold therapeutic potential in endotoxin induced hepatotoxicity. This study result were comparable to those of Araz and fellow who demonstrated in 2013 that this steroid succeeded in reducing LPS induced lung injury in rat, when given 30 minutes before and after LPS. ${ }^{9}$

Coherent with our opinion, Wang et al demonstrated that dexamethasone (given 1 hour before LPS) abolished LPS produced liver injury as proved by restoration of serum ALT and hepatic inflammation. ${ }^{22}$ Serum TNF- $\alpha$ and IL-6, elevated in serum and liver tissues after LPS exposure, were down-regulated by dexamethasone. Dexamethasone therapeutic adequacy in LPS induced liver dysfunction was also supported by $\mathrm{Li}$ and colleagues. ${ }^{38}$

Dexamethasone in combination with melatonin was worked upon in Group 7. The inspiration came from the question if the potent anti-inflammatory role of dexamethasone and strong antioxidant activity of melatonin works additively in aversion of liver injury in endotoxemia or not. The combination effectively and efficiently attenuated LPS induced hepatotoxicity but not additively. Serum ALT and AST levels dropped to statistically significant concentration when compared to Group 2 (LPS Group) but inconsiderably when compared to dexamethasone and melatonin alone post-treatment in Group 4 and Group 9 respectively. Similar results were also applicable to histopathological analysis. Concomitant treatment of dexamethasone and melatonin favourably reduced hepatic inflammation but as much as seen with alone agent post-treatment. unlike this study many studies have showed synergistic effect of dexamethasone and melatonin in various inflammatory disorders having somewhat same pathophysiology as in sepsis. ${ }^{39,40}$ The discrepancy may be due to alteration in this methodology and pathophysiology of LPS induced hepatotoxicity.

This study clearly demonstrates that both dexamethasone and melatonin restored LPS induced liver injury in this animal model. Melatonin being a broad-spectrum antioxidant decline liver serum marker levels 1-19\% more than that of dexamethasone, however this result was not statistically significant.

Both the tested drugs shifted histopathological grading from marked inflammation to minimal inflammation in almost all liver cross sections of given animal.as many scientist not only negate the beneficial role of steroid in sepsis induced organ failure but also associate its use with further adverse effects like new episodes of sepsis, gastrointestinal bleeding, delayed wound healing, hypernatremia, hyperglycemia and neuromuscular weakness, melatonin seems to be a new promising drug in LPS/endotoxin induced hepatic dysfunction. 


\section{CONCLUSION}

Intraperitoneal administration of $10 \quad \mathrm{mg} / \mathrm{kg}$ Lipopolysaccharide of serotype $E$. coli in mice produced a good model to study sepsis induced liver failure. Perhaps due to strong and extended antioxidant role of Melatonin, the results of group 7 and group 8 clearly demonstrates its encouraging role in LPS induced hepatotoxicity. The hepatoprotective effect of melatonin is comparable to that of dexamethasone, lowering the risk of serious adverse effects attributed to steroid use in sepsis induced organ failure. However future research should be done with combination therapy.

Funding: No funding sources Conflict of interest: None declared

Ethical approval: The study was approved by the Institutional Ethics Committee

\section{REFERENCES}

1. Angus DC, Linde-Zwirble WT, Lidicker J, Clermont G, Carcillo J, Pinsky MR. Epidemiology of severe sepsis in the United States: analysis of incidence, outcome, and associated costs of care. Critical care medicine. 2001 Jul 1;29(7):1303-10.

2. Kumar G, Kumar N, Taneja A, Kaleekal T, Tarima S, McGinley E, et al. Nationwide trends of severe sepsis in the 21st century (2000-2007). Chest. 2011 Nov $1 ; 140(5): 1223-31$.

3. Martin G, Brunkhorst FM, Janes JM, Reinhart K, Sundin DP, Garnett K, et al. The international PROGRESS registry of patients with severe sepsis: drotrecogin alfa (activated) use and patient outcomes. Critical care. 2009 Jun;13(3):R103.

4. Nesseler N, Launey Y, Aninat C, Morel F, Mallédant Y, Seguin P. Clinical review: The liver in sepsis. Critical care. 2012 Oct;16(5):235.

5. Arafah BM. Hypothalamic pituitary adrenal function during critical illness: limitations of current assessment methods. J Clin Endocr Metab. 2006 Oct 1;91(10):3725-45.

6. Sprung CL, Annane D, Keh D, Moreno R, Singer M, Freivogel K, et al. Hydrocortisone therapy for patients with septic shock. N Engl J Med. 2008;358:111-24.

7. Aytac HO, Iskit AB, Sayek I. Dexamethasone effects on vascular flow and organ injury in septic mice. J Surg Res. 2014;188:496-502.

8. Batalhao ME, Moreto V, Stabile AM, AntunesRodrigues J, Carnio EC. Role of dexamethasone on vasopressin release during endotoxemic shock. Regul Peptides. 2008; 147:67-71.

9. Araz O, Demirci E, Ucar EY, Calik M, Pulur D, Karaman A, et al. Comparison of reducing effect on lung injury of dexamethasone and bosentan in acute lung injury: an experimental study. Multidscip Respir M. 2013;8:74.

10. Wang ZH, Liang YB, Tang H, Chen ZB, Li ZY, Hu $\mathrm{XC}$, et al. Dexamethasone down-regulates the expression of microRNA-155 in the livers of septic mice. PLoS One. 2013 Nov 11;8(11):e80547.

11. Patel, GP, Balk, RA. Systemic steroids in severe sepsis and septic shock. Am J Resp Crit Care. 2012;185:1339 .

12. Marik PE. Glucocorticoids in sepsis: dissecting facts from fiction. Crit Care. 2011;15:158.

13. Batzofin BM, Sprung CL, Weiss YG. The use of steroids in the treatment of severe sepsis and septic shock. Best Pract Res Cl En. 2011;25:735-43.

14. Liu F, Ng TB. Effect of pineal indoles on activities of the antioxidant defense enzymes superoxide dismutase, catalase, and glutathione reductase, and levels of reduced and oxidized glutathione in rat tissues. Biochem Cell Biol. 2000;78:447-53.

15. Sewerynek E, Melchiorri D, Reiter RJ, Ortiz GG, Lewinski A. Lipopolysaccharide-induced hepatotoxicity is inhibited by the antioxidant melatonin. Eur J Pharm-Environ. 1995;293:327-34.

16. Srinivasan V, Pandi-Perumal SR, Spence, DW, Kato H, Cardinali DP. Melatonin in septic shock: Some recent concepts. J Crit Care. 2010;25(4):656-e1.

17. Gitto E, Karbownik M, Reiter RJ, Tan DX, Cuzzocrea S, Chiurazzi P, et al. Effects of melatonin treatment in septic newborns. Pediatric research. 2001 Dec;50(6):756.

18. De Filippis D, Iuvone $T$, Esposito $G$, Steardo L, Herman Arnold G, Pelckmans Paul A, et al. Melatonin reverses lipopolysaccharide-induced gastro-intestinal motility disturbances through the inhibition of oxidative stress. J of Pin Reser. 2008 Jan 1;44(1):4551.

19. Dellinger RP, Levy MM, Rhodes A, Annane D, Gerlach H, Opal SM, et al. Surviving Sepsis Campaign: international guidelines for management of severe sepsis and septic shock, 2012. Intens Care Med. 2013 Feb 1;39(2):165-228.

20. Bernard AM, Bernard GR. The immune response: targets for the treatment of severe sepsis. International journal of inflammation. 2012;2012.

21. Wei SD, Li JZ, Liu ZJ, Chen Q, Chen Y, Chen M, et al. Dexamethasone attenuates lipopolysaccharideinduced liver injury by down regulating glucocorticoid-induced tumor necrosis factor receptor ligand in Kupffer cells. Hepatol Res. 2011;41(10):989-99.

22. Wang X, Nelin LD, Kuhlman JR, Meng X, Welty SE, Liu Y. The role of MAP kinase phosphatase-1 in the protective mechanism of dexamethasone against endotoxemia. Life sciences. 2008 Nov 7;83(1920):671-80.

23. Rishi P, Bharrhan S, Bhalla MP, Koul A, Chopra K. Inhibition of endotoxin-induced hepatotoxicity by melatonin in rats. International journal of biomedical science: Int J Biomed Sci. 2008 Jun;4(2):103.

24. Irie K, Fujii E, Ishida H, Wada K, Suganuma T, Nishikori T, et al. Inhibitory effects of cyclic AMP elevating agents on lipopolysaccharide (LPS)-induced microvascular permeability change in mouse skin. Brit J Pharmacol. 2001 May 1;133(2):237-42. 
25. González-Renovato ED, Alatorre-Jiménez M, BitzerQuintero OK, Sánchez-Luna S, Flores-Alvarado LJ, Romero-Dávalos R, et al. Effect of Nutrisim $\odot$ on endotoxic shock induced by lipopolysaccharide from Escherichia coli: 0111: b4 in rats: structural study of liver, kidney and lung. J Clin Exp Pathol. 2013;4(1):15.

26. Brunt EM. Grading and staging the histopathological lesions of chronic hepatitis: the Knodell histology activity index and beyond. Hepatology. 2000 Jan $1 ; 31(1): 241-6$

27. Schmöcker C, Weylandt KH, Kahlke L, Wang J, Lobeck H, Tiegs G, et al. Omega-3 fatty acids alleviate chemically induced acute hepatitis by suppression of cytokines. Hepatology. 2007 Apr 1;45(4):864-9.

28. Anwer S, Zafar MH, Awan HM, Shamim Mumtaz NA, Hayat A, Memon BA, et al. Study on the prevalence of enterobacteriacae in hospital acquired and community acquired infections. Pak J Med Res. 2002 Jan;41(1):39-40.

29. Fink MP. Animal models of sepsis. Virulence. 2014 Jan 1;5(1):143-53.

30. Buness A, Roth A, Herrmann A, Schmitz O, Kamp H, Busch K, et al. Identification of metabolites, clinical chemistry markers and transcripts associated with hepatotoxicity. PloS one. 2014 May 16;9(5):e97249.

31. Klopfleisch R. Multiparametric and semiquantitative scoring systems for the evaluation of mouse model histopathology-a systematic review. BMC Vet Res. 2013;9(1):123.

32. Nemzek JA, Hugunin K, Opp MR. Modeling sepsis in the laboratory: merging sound science with animal well-being. Comparative medicine. $2008 \mathrm{Apr}$ 16;58(2):120-8.

33. Lowes DA, Webster NR, Murphy MP, Galley HF. Antioxidants that protect mitochondria reduce interleukin-6 and oxidative stress, improve mitochondrial function, and reduce biochemical markers of organ dysfunction in a rat model of acute sepsis. Brit J Anaesth. 2013 Mar 1;110(3):472-80.

34. Wang H, Xu DX, Lv JW, Ning H, Wei W. Melatonin attenuates lipopolysaccharide (LPS)-induced apoptotic liver damage in D-galactosamine-sensitized mice. Toxicology. 2007 Jul 31;237(1-3):49-57.

35. Crespo E, Macías M, Pozo D, Escames G, MartÍn M, Vives F, et al. Melatonin inhibits expression of the inducible NO synthase II in liver and lung and prevents endotoxemia in lipopolysaccharide-induced multiple organ dysfunction syndrome in rats. The FASEB J. 1999 Sep 1;13(12):1537-46.

36. Carrillo-Vico A, Lardone PJ, Naji L, FernándezSantos JM, Martín-Lacave I, Guerrero JM, et al. Beneficial pleiotropic actions of melatonin in an experimental model of septic shock in mice: regulation of pro-/anti-inflammatory cytokine network, protection against oxidative damage and antiapoptotic effects. J Pineal Res. 2005;39:400-8.

37. Wu JY, Tsou MY, Chen TH, Chen SJ, Tsao CM, Wu CC. Therapeutic effects of melatonin on peritonitisinduced septic shock with multiple organ dysfunction syndrome in rats. J Pineal Res. 2008;45(1):106-16.

38. Li YX, Wang YZ, Wang JL, Xie JM, Kang HB, Liu YP. The Therapeutic Effect of Dexamethasone on Liver Injury Rat induced By Lps/D-Galn. J of Inner Mongolia Agricultural University (Natural Science Edition). 2012;3:029.

39. Campolo M, Ahmad A, Crupi R, Impellizzeri D, Morabito R, Esposito E, et al. Combination therapy with melatonin and dexamethasone in a mouse model of traumatic brain injury. J Endocrinol. 2013;217:291301.

40. Li ZQ, Liang GB, Xue YX, Liu YH. Effects of combination treatment of dexamethasone and melatonin on brain injury in intracerebral hemorrhage model in rats. Brain Res. 2009;1264:98-103.

Cite this article as: Khan A, Afzal A, Rauf A, Waheed A. Comparative efficacy of melatonin in attenuation of endotoxin/LPS induced hepatotoxicity in BALB/c mice. Int J Basic Clin Pharmacol 2018;7:1191-9. 